\title{
Doubtful Debts Allowance Develoment: Stages and Methods of Calculation
}

\author{
Kulikova L.I.a \\ Garyncev A.G. ${ }^{b}$ \\ Goshunova A.V.c \\ a bc Kazan Federal University, Institute of Management, Economics and Finance, Kazan, 420008, Russia
}

\section{Doi:10.5901/mjss.2015.v6n1s3p448}

\begin{abstract}
The paper investigates the problem of doubtful debts allowance development for the purposes of receivables reflection in the accounting (financial) statements. Comparison of approaches to forming the allowance in compliance with the US, Russian and international accounting standards is fulfilled. It is proved that the allowance of doubtful debts formation should be based on the principle of accounting conservatism. In this case, it is advisable to use the method of accounts receivable aging based on the probability of payment coefficient. This coefficient represents the best assessment by the managers of the possible amount of the accounts left without repayment by the buyers judging from the past experience of relations with the debtors. The steps of forming an allowance are described in detail, basing on the certain procedures fulfillment.
\end{abstract}

Keywords: the debtor, the debt, allowance, doubtful, accountancy, US GAAP, IAS

\section{Introduction}

Historically, the emergence of receivables is associated with the development of commercial lending caused by a lack of available cash assets. To increase the company's revenues the enterprises were forced to ship the products on the transfer conditions of payment at a later date "on the pledge of the word" of the buyer. However, this situation can lead to the occurrence of the so-called "bad" debtors causing doubt about the repayment of their debts [1, 2]. For these purposes the allowances of doubtful debts is established for reducing of the amount of receivables reflected in the financial statements [3]. However, at present there are no specific methods of the said allowance formation in the existing Russian laws and regulations on accounting. In our research, we have developed approaches to the allowance of the doubtful debts formation by implementing certain procedures carried out in stages.

\section{Method}

The idea of an allowance for doubtful debts formation came first to the bankers. Thus, part of the Bank Medici policy, which was one of the oldest Florentine banks operating in the XII-XIV centuries, was the establishing of such allowance as the act preceding distribution of profits. The idea of the allowance creating was implemented in other countries. Thus, J.Peel in the book "Paths to Perfection" published in England in 1569 suggested separating the doubtful debts of the debtors in the accounting, so that the owner could know about it [4].

At present, in accordance with international financial reporting standards receivables are treated as a financial asset $[5,6]$. Under the IAS 39, each financial asset is subject to impairment test, which is related to the excess of the carrying value of the asset over its estimated recoverable amount. As of the reporting date the company should assess the evidence of the objective data for possible impairment of the financial asset [7]. The identified probable failure to obtain the principal debt and the interest by the receivable necessitates the calculation of allowances for the impairment. The allowance volume reduces the carrying amount of the financial asset to its estimated recoverable amount [8].

Thus, international standards oblige organizations to form an allowance for doubtful debts in the event of any impairment indications [9]. In this case, the allowance is formed basing on operational data of debts payment, as well as on the basis of: the probability of the debt recovery; repayment of the past debts depending on the term of the debt; possibility of repayment judging from the data of the client [10].

US accounting standards (US GAAP) stipulate basically two methods of determining doubtful debts during the reporting period for calculation of the cost value for bad debts: percentage of net sales method and accounts receivable 
aging method. According to the second method the accountancy department fulfills ranking of accounts by terms of their repayment, each group of accounts is determined by the forecasted percentage of doubtful debts. This approach helps the management of the company to determine the policies of the loan provision and all settlement operations [11].

L.I.Gomberg - corresponding member of the Academic Society of Accountants in Paris, member of the International Association of Accountants was the first in Russia who wrote in 1903 in the journal "Accounting" of the doubtful receivables allowance creation and of the receivables reflection with consideration of allowance. He offered his method of the allowances determining for "bad" debtors.

In accordance with the Rules of the balance sheet drawing approved by the Resolution of the Council of Labor and Defense of 26 April, 1928, the creation of doubtful debts allowance was announced obligatory. Famous Russian balance issues researcher N.A.Blatov described the procedure of an allowance forming in the following way: "Doubtful debts allowance is created for the part of the debts, which seems doubtful. Alongside with bringing an active cost of debts calculated by the nominal value to the real value seeming fairly reliable for receiving, the allowance at the same time seeks to clarify the calculations by the results of the neighboring years, laying on a fiscal year the losses on debts that have become doubtful in the course of the year" [12].

It should be noted that only from 1 January, 1992 the idea of doubtful debts allowance obtained its practical implementation in the post-Soviet Russia. By the Regulation on accounting and reporting in the Russian Federation approved by the Order No 34n of the Ministry of Finance of the Russian Federation of 29 July, 1998, which is still effective at present, it has been established that the allowance for doubtful debts is created on the basis of the accounts receivable inventory in the organization. Thus, the receivables of the organization are considered doubtful if they are not repaid or with high level of probability will not be repaid within the period specified by the contract, and are not provided with appropriate guarantees. The allowance value is determined separately for each bad debt, depending on the financial position (solvency) of the debtor and the estimation of the probability of debt repayment in full or in part. The allowance sums recognized in the financial results of the organization.

The allowance size is not shown separately in the balance sheet, but the receivables in the assets are recognized in the net assessment, that is less the formed allowance. Let us imagine a situation, where all receivables will be doubtful, that is outstanding at the stipulated time and not provided by any guarantees. Then, according to the applicable accounting rules the allowance of doubtful debts will be formed for the entire amount of the receivables.

Back in 1927 N.R. Weizmann in his book "The course of the accounting study" supposed that a significant amount of reserves for expected defaults in payment may hit creditors and investors upon the idea of the unreliable enterprise clientele. According to N.R. Weizmann, a limit should be set for an allowance formation. An allowance in the amount of 5$8 \%$ of receivables - this could be a fairly considerable value [13].

N.R. Weizmann believed that verification of receivables requires a thorough study of the entire trading activity of the enterprise as well as the nature of its clientele. Here the definition of usefulness or doubtfulness of certain requirements to the third parties almost always depends on the free discretion of the enterprise. According to N.R. Weizmann, the study of receivables reliability requires the accountancy department to submit the documents confirming the accuracy of balances on transactions with the major debtors (such documents are the debtors letters received in response to an open account statements sent to them).

In 1926 I.R. Nikolaev in his book "The problem of balance feasibility" cited the standards of Swiss and Italian firms dividing the receivables into three classes:

- the first class - definitely reliable debts, for which a reserve fund is formed in the amount of $5 \%$ of their value for discounts, interest, exchange losses, costs of obtaining, etc.;

- $\quad$ the second class - average debts, leaving hesitant about their total value; they should be shown $80 \%$ of their amount;

- the third class - doubtful debts, which must be shown $50 \%$ of their amount [14].

Professor Ya.V. Sokolov in 2000 believed, that the accounting policy should stipulate a unified rate for all receivables. In his opinion, "The establishment of allowance by experimental way as a probability of each individual debt repayment - would be a deeply wrong approach, since the meaning of provisioning is reduced to the determination of the average expectation of possible changes of the allowance forming value" [15].

It should be noted, that the allowance of doubtful debts formation raises many questions in the present practice of the Russian organizations. What is the way to confirm the calculation of the allowance? Which method shall be used for determining of the allowance amount? In the uncertain situation many Russian organizations often do not regularly evaluate the recoverability of specific receivables. Consequently, the receivables are recognized in the accounting reports in full, which causes reflection of unrealistic amounts of debt. 


\section{Results}

Doubtful debts allowance represents the estimated value of the receivables' impairment, roughly determined or calculated basing on professional accounting judgments in the absence of a precise method for its determining. In our opinion, by the reserve formation it is necessary to base on the precautionary principle. For preventing of hidden allowances, the allowance for doubtful accounts must include only the excess amount of receivables over payables to the same counterparty $[16,17]$.

We believe that the method of the reserve formation implies fulfillment of certain calculations (procedures), consisting of several stages (Fig. 1).

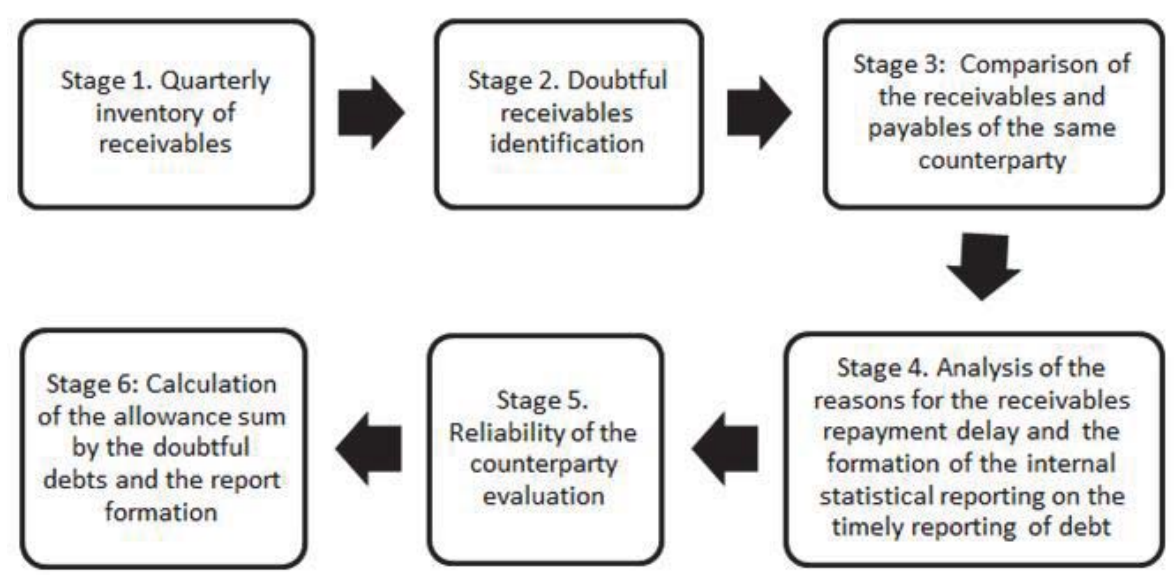

Fig. 1. Stages of allowance for doubtful debts formation procedure

Stage 1. Quarterly inventory of receivables fulfillment at the end of each reporting period of interim reporting.

Stage 2. Identification of overdue receivables not supported by the appropriate guarantees, as well as accounts receivable from the counterparties under the bankruptcy procedure or litigation procedure for the recovery of receivables $[18,19,20]$.

Stage 3. Comparison of receivables and payables of the same counterparty. The overdue accounts receivable not guaranteed by the counterparties with accounts payable are excluded from the list of the debtors identified in step 2:

$\mathrm{Dc}=\mathrm{Pdc}-\mathrm{Rdc},(1)$

where Dc - debt of the counterparty

Pdc - overdue receivables by the counterparty,

Rdc - payables by the counterparty.

If $D c<0$, then the debt is not regarded as doubtful.

If $D c>0$, then the difference is considered as doubtful debts in case the delay in repayment period exceeds the time limits established by the contract by 45 calendar days.

Stage 4. Analysis of the reasons for the receivables repayment delay and the formation of the internal statistical reporting on the timely repayment of debt. It is advisable to submit the results of the analysis in the register of the following form (Table 1).

Table 1. Accounting register of untimely debt repayment

\begin{tabular}{|c|c|c|l|}
\hline No & Counterpart & $\begin{array}{c}\text { Cases of untimely debt repayment in three years } \\
\text { preceding the reporting period }\end{array}$ & Term of delay \\
\hline 1 & "LTD" LLC & & No cases of untimely debt repayment \\
\hline 2 & "Stilus" LLC & 3 quarter, 2011 & $\begin{array}{l}\text { The debt is repaid 6 days after the deadline } \\
\text { specified in the contract }\end{array}$ \\
\hline 3 & "Trust-cold" OJSC & 1 quarter, 2014 & $\begin{array}{l}\text { The debt is repaid 10 days after the deadline } \\
\text { specified in the contract }\end{array}$ \\
\hline
\end{tabular}

Subsequently, the internal statistics of the timely repayment of the debt in three years preceding the reporting is used 
when assessing the reliability of the counterparty fulfilled in Phase 5 .

Stage 5. Reliability of the counterparty evaluation. All counterparties can be combined into 4 groups of reliability level. The assignment of the counterparty to one or another group is done on condition of its compliance with one or more reliability criteria set out in column 3 of the Table 2.

Table 2. Grouping of counterparties

\begin{tabular}{|c|c|c|c|c|}
\hline $\mathrm{N}$ & $\begin{array}{l}\text { Group of } \\
\text { counterparties name }\end{array}$ & $\begin{array}{l}\text { Criteria for classification of counterparties to the } \\
\text { appropriate group }\end{array}$ & $\begin{array}{l}\text { Coefficient interval } \\
\text { of payment } \\
\text { probability }\end{array}$ & $\begin{array}{l}\text { Determination of the of payment } \\
\text { probability coefficient (within the } \\
\text { interval specified in the column 4) }\end{array}$ \\
\hline 1 & 2 & 3 & 4 & 5 \\
\hline 1 & $\begin{array}{l}\text { I group of risk } \\
\text { Reliable } \\
\text { counterparties }\end{array}$ & $\begin{array}{l}\text { - Counterparty is included into a group of companies by } \\
\text { formation of the consolidated reporting (parent, } \\
\text { subsidiary, affiliate, joint venture company); } \\
\text { - the overdue debt has been settled by the date of the } \\
\text { allowance calculation for the doubtful debts, as it has } \\
\text { been repaid both upon the reported date, which is } \\
\text { specified as the date for the reserve calculation, and } \\
\text { before the date of the reserve formation. } \\
\text { These counterparties are assigned to the II or to the III } \\
\text { group of risk in case of the failure to settle the debt } \\
\text { within } 1 \text { year from the moment of the debt occurrence. }\end{array}$ & - & $\begin{array}{l}\text { The debt sums of these } \\
\text { counterparties are not considered in } \\
\text { the allowance for the doubtful debts } \\
\text { calculation }\end{array}$ \\
\hline 2 & $\begin{array}{l}\text { II Group of risk } \\
\text { Average } \\
\text { counterparties }\end{array}$ & $\begin{array}{l}\text { There are no delays in the debt settlement of these } \\
\text { counterparties (basing on the internal statistical data } \\
\text { studied for three years preceding the reported period) }\end{array}$ & from 0.4 to 0.6 & \multirow{2}{*}{$\begin{array}{l}\text { The entire sum of the debt by this } \\
\text { counterparty adjusted for the } \\
\text { coefficient of expert estimation is } \\
\text { taken for calculation of allowance for } \\
\text { the doubtful debts. }\end{array}$} \\
\hline 3 & $\begin{array}{l}\text { III group of risk } \\
\text { Unreliable } \\
\text { counterparties }\end{array}$ & $\begin{array}{l}\text { There are delays in the debt settlement of these } \\
\text { counterparties (basing on the internal statistical data } \\
\text { studied for three years preceding the reported period); } \\
\text { There are no statistical data of timely debt settlement, as } \\
\text { there has been no previous business relationship with } \\
\text { this counterparty. }\end{array}$ & from 0.6 to 0.9 & \\
\hline 4 & $\begin{array}{l}\text { IV group of risk: } \\
\text { Critical } \\
\text { counterparties }\end{array}$ & $\begin{array}{l}\text { There are: } \\
\text { - applications of the bankruptcy procedure } \\
\text { commencement; } \\
\text { - pending lawsuits with the counterparty of the debt } \\
\text { recovery; } \\
\text { - documents confirming that the leadership of the } \\
\text { organization has made a decision of the overdue debt } \\
\text { recovery from the counterparty by way of the lawsuit } \\
\text { (internal memorandum, orders, regulations etc.) } \\
\text { Counterparty is a natural person (individual } \\
\text { entrepreneur) }\end{array}$ & 1.0 & \\
\hline
\end{tabular}

Stage 6: Calculation of the allowance for doubtful accounts and report formation.

Calculation of the allowance sum for doubtful accounts is carried out by the Commission in charge of dealing with accounts receivable for each debt and each debtor separately by multiplying the doubtful debt amount by the corresponding coefficient of payment probability (CPP).

The results of the analysis in the previous phases are recorded in the report "Calculation of the allowance sum for doubtful debts" (Table 3).

Table 3. The calculation of the allowance sum for doubtful debts

\begin{tabular}{|c|c|c|c|c|c|c|}
\hline No & $\begin{array}{c}\text { Name and } \\
\text { address of the } \\
\text { debtor }\end{array}$ & $\begin{array}{c}\text { Basis of the receivables } \\
\text { occurrence (for anything) }\end{array}$ & $\begin{array}{c}\text { Commencement } \\
\text { date }\end{array}$ & $\begin{array}{c}\text { Difference between the } \\
\text { outstanding receivables and } \\
\text { payables, rub. }\end{array}$ & $\begin{array}{c}\text { Coefficient of } \\
\text { payment } \\
\text { probability }\end{array}$ & $\begin{array}{c}\text { The allowance } \\
\text { value, rub. }\end{array}$ \\
\hline 1 & 2 & 3 & 4 & 5 & 6 & $7=5^{\star} 6$ \\
\hline 1 & "Gamma" LLC & For the shipped products & $\begin{array}{c}05 \text { November, } \\
2014\end{array}$ & 590000 & 0.7 & 413000 \\
\hline
\end{tabular}




\section{Conclusion}

Our proposed method of calculating the allowance for doubtful debts will allow to realize the principle of prudence (accounting conservatism). This is necessary both for the implementation of internal control over the debtors, and for disclosing of information about the accounts receivable of the organization in the financial statements. Allowance for doubtful debts must be formed basing on the evaluation of the state of affairs in the organization and on the expected future economic benefits in settlement of accounts receivable.

\section{References}

Armstronga, C.S, Guaya, W.R., Weberb, J.P. The role of information and financial reporting in corporate governance and debt contracting // Journal of Accounting and Economics 50(2-3), 2010. pp. 179-234.

Peechera, M.E., Solomonb, I., Trotman, K.T. An accountability framework for financial statement auditors and related research questions // Accounting, Organizations and Society 38(8), 2013. pp. 596-620.

Dosamantes, C.A.D. The Relevance of Using Accounting Fundamentals in the Mexican Stock Market // Journal of Economics Finance and Administrative Science 18, 2013. pp. 2-10.

Kovalev, V.V., Kovalev Vit.V. Analysis of the balance sheet or how to understand the balance. Prospect Publishing House, Russia, 2009.pp: 448 p.

Zhang, J. The contracting benefits of accounting conservatism to lenders and borrowers // Journal of Accounting and Economics 45(1), 2008. pp. 27-54.

Nobesa, C., Stadler, C. How arbitrary are international accounting classifications? Lessons from centuries of classifying in many disciplines, and experiments with IFRS data // Accounting, Organizations and Society 38(8), 2013. pp. 573-595.

Beauchamp Jr., N.J., Hurt, C.J. Chapter 9 - Accounts Receivable // Radiology Business Practice. How to Succeed, 2008. pp. 118-132.

Kanagaretnama, K., Krishnanb, G.V., Loboc, G.J. Is the market valuation of banks' loan loss provision conditional on auditor reputation? // Journal of Banking \& Finance 33(6), 2009. pp. 1039-1047.

Bushmana, R.M., Williams, C.D. Accounting discretion, loan loss provisioning, and discipline of Banks' risk-taking // Journal of Accounting and Economics 54(1), 2012. pp. 1-18.

Kulikova L.I., Goshunova A.V. Science of Balance Preparation: Substance and Stages of Development in Russia // Mediterranean Journal of Social Sciences 5(24), 2014. pp. 49-51.

Kulikova L.I., Gafieva G.M. Development of Financial Reporting Principles // Mediterranean Journal of Social Sciences 5(24), 2014. pp. 38-40.

Marilenaa, Z., Corina, I. Embellishment of Financial Statements Through Creative Accounting Policies and Options 62, 2012. pp. 347351.

Needles B., Anderson, H., Caldwell, D. Accounting principles. 2nd ed., a stereotype. Finance and statistics Publishing House, Russia, 1996. pp: 496.

Blatov, N.A. Science of balance preparation (general course). State Trade Publishing House, Russia, 1931. pp: 320.

Weizmann, N.R. Course of science of balance preparation. Central Union Publishing House, Russia, 1927. pp:241.

Nikolaev, I.R. The problems of the reality of the balance sheet. Publishing house «Economy of economic education», Russia, 1926. pp: 109.

Sokolov, Y.A. Fundamentals of the theory of accounting. Finance and statistics Publishing House, Russia, 2000. pp: 496.

Kulikova L.I., Grigoryeva L.L., Gubaidullina A.R.The Interrelation between the Professional Judgment of the Accountant and the Quality of Financial Reporting // Mediterranean Journal of Social Sciences 5(24), 2014. pp. 61-64. 